\title{
Syncope in Makkan Arabic Fast Speech: A Stratal-OT Analysis
}

\author{
Rawiah S. Kabrah \\ Department of English, College of Social Sciences, Umm Al-Qura University, Saudi Arabia
}

Copyright $\bigcirc 2019$ by authors, all rights reserved. Authors agree that this article remains permanently open access under the terms of the Creative Commons Attribution License 4.0 International License

\begin{abstract}
Syncope is a pervasive phenomenon in Arabic, in general. In Makkan Arabic in particular, syncope occurs both in careful speech as well as in fast speech. This paper examines syncope in fast speech where it applies to initial syllables in words giving rise to syllables that contain complex onsets which are otherwise prohibited in the language. It further examines the phonotactic constraints that play a role in the application of syncope as well as the constraints that can block syncope in the same environments. Other Arabic dialects that manifest the same behavior of syncope in fast speech are considered. The analysis of the Makkan data is done within the framework of Stratal-Optimality theory. The paper lends evidence to the fact that postlexical level includes the level of careful speech and that of fast speech each with its own ranking of constraints.
\end{abstract}

Keywords Fast Speech, Makkan Arabic, Optimality Theory, Postlexical Levels, Stratal-OT, Syncope

\section{Introduction}

Studies on fast speech phenomena disagree as to the nature of these processes and whether they should be considered as phonological or phonetic processes (e.g. obstruents assimilation flanking a sonorant in Russian [1], schwa elision in English [2], [3], [4], and [5]), just to name a few.

Syncope in Makkan Arabic (henceforth MA) normal speech has received extensive attention in the literature on Makkan (e.g. [6], [7], [8], [9], and [10]). Abu Mansour [8], [11], and [12] have provided a detailed analysis of this phonological process in a rule-based framework as well as in Optimality Theory.

Abu Mansour [8] observes that in Makkan Arabic all high vowels in open unstressed syllables are deleted. Syncope is, however, blocked if it yields syllables with complex margins (complex onsets or codas).

Kabrah [10] restricts syncope in Makkan to the high front vowel (i.e. /u/ does not delete). She also adds that syncope underapplies in the broken plurals and loan words from standard Arabic. Both Abu Mansour [8] and Kabrah [10] consider syncope as a postlexical process in the Makkan dialect. Abu Mansour [12] looks at phrasal syncope in MA and maintains that all high vowels are deleted at the phrasal level.

This paper aims at examining syncope in Makkan Arabic fast speech to determine whether it is a phonological or a phonetic process, to describe the context in which syncope occurs in a given rate of speech, and to provide an OT analysis of syncope at different rates of speech thus showing the different constraints that conspire to cause deletion at each level.

The rest of the paper is organized as follows. In section 2 , I give a detailed description of the Makkan data. Section 3 outlines the theoretical framework. Section 4 includes analysis of syncope both in normal and fast speech. In section 5, I provide a description of syncope as a fast speech phenomenon in Nhoolah Arabic, a variety of Hadramuti Arabic, and Cairene Arabic. Section 6 concludes the paper.

\section{Data}

Syncope is a pervasive phonological process in Arabic such that the Arabic dialects are differentiated on the basis of the vowels they syncopate [13]. Differential dialects, such as Makkan, only delete high vowels that occur in open unstressed syllables [7], [8], [10], and [12]. In contrast, in Non-differential dialects such as Tripolitanian Arabic [14] both high and low vowels in open unstressed syllables are syncopated to avoid a sequence of light syllables.

Makkan Arabic has two rules of syncope. Both rules are postlexical due to the fact that they have no impact on stress and they do not interact with it. The first rule is obligatory and it occurs in medial position where the second vowel in an open syllable gets deleted (e.g., $\mathrm{CVVCVCV} \Rightarrow \mathrm{CVVCCV}$, and $\mathrm{CVCVCV} \Rightarrow \mathrm{CVCCV})$. This is typically the case in normal speech. Representative 
examples are given in (1).

(1) Syncope in careful speech

\begin{tabular}{|c|c|c|c|}
\hline & Input & Output & Gloss \\
\hline a. & șaaћibátu & șađbátu & 'his friend (f)' \\
\hline b. & káatiba & káatba & 'female writer' \\
\hline c. & Šíribu & Šírbu & 'they drank' \\
\hline d. & mísiku & mísku & 'they held' \\
\hline E & yiráahinu & yiráahnu & 'they bet' \\
\hline
\end{tabular}

The second syncope rule is optional and it occurs in fast speech, where the high vowel in the first syllable is syncopated, and giving rise to a syllable with a complex onset, which is otherwise prohibited in careful speech (e.g. C $\underline{V}$ VVV $\Rightarrow$ CCVVC). Syncope in fast speech occurs within words, as shown in (2), as well as across morpheme boundaries, as evident in (3).

\section{(2) Syncope within words in MA fast speech}

\begin{tabular}{|c|c|c|c|}
\hline & Input & Output & Gloss \\
\hline a. & bigaala & bgaala & 'supermarket' \\
\hline b. & risaala & rsaala & 'letter' \\
\hline c. & fișaal & fṣaal & 'haggling' \\
\hline d. & mudarris & mdarris & 'male teacher' \\
\hline e. & Šumaax & šmaax & 'head cover' \\
\hline
\end{tabular}

(3) Syncope across morpheme boundaries in MA fast speech

\begin{tabular}{|c|c|c|c|}
\hline & Input & Output & Gloss \\
\hline a. & yi-ruuh & yruuћ & 'he goes' \\
\hline b. & ti-ruuh & truuh & 'she goes' \\
\hline c. & ni-ruuћ & nruuћ & 'we go' \\
\hline d. & ti-ruuhi & truuћi & 'you (f) go' \\
\hline e. & yi-ruuhu & yruuћu & 'they go' \\
\hline
\end{tabular}

(4) Syncope in the first syllable of the broken plural

\begin{tabular}{|c|c|c|c|}
\hline & Input & Output & Gloss \\
\hline a. & kilaab & klaab & 'dogs' \\
\hline b. & bisaas & bsaas & 'cats' \\
\hline c. & ružuul & ržuul & 'feet/legs' \\
\hline d. & SuDaam & SDaam & 'bones' \\
\hline e. & rumuuš & rmuuš & 'eye lashes' \\
\hline f. & bilaad & blaad & 'countries' \\
\hline
\end{tabular}

Syncope in fast speech underapplies even when its structural description is met. This happens in forms where deletion results in two consonants that are either stridents or stops sharing the same place of articulation. Relevant examples are given in (5).
(5) Underapplication of syncope in MA

\begin{tabular}{|c|c|c|c|}
\hline & Input & Output & Gloss \\
\hline a. & tiDaayig & *tDaayig & 'to bother' \\
\hline b. & tidawwir & *tdawwir & 'to look for' \\
\hline c. & žuzaam & *žzaam & 'skin disease' \\
\hline d. & žuzuur & *žzuur & 'roots' \\
\hline e. & žusuur & *žsuur & 'bridges' \\
\hline f. & sužuun & *sžuun & 'prisons' \\
\hline G & šužuun & *šžuun & 'emotions' \\
\hline
\end{tabular}

Syncope is blocked in forms where the vowels in the first syllables are stressed as shown in examples (6). Note that in these examples, the second vowel should be deleted in careful speech, however, the vowel fails to syncopate to preserve the template.

\section{(6) Underapplication of syncope in the broken plural} CVCEC-V

\begin{tabular}{|c|c|c|c|}
\hline & Input & Output & Gloss \\
\hline a. & súrur-u & *sruru & 'his beds' \\
\hline b. & múdun-u & *mdunu & 'his cities' \\
\hline c. & múdus-i & *mdusi & ‘my slippers’ \\
\hline d. & súћub-u & *sћubu & 'his clouds' \\
\hline e. & lúћuf-i & $* \mid \hbar u f i$ & 'my blankets' \\
\hline f. & rúkab-u & ${ }^{*}$ rkabu & 'his knees' \\
\hline g. & үúraf-u & ${ }^{*} \gamma \mathrm{rafu}$ & 'his bedrooms' \\
\hline
\end{tabular}

It should be borne in mind that complex onsets are allowed only in the output of fast speech syncope. In word-medial position, syllables with complex margins (onsets and codas) are categorically banned. This is evident from the examples in (7).

\section{(7) Underapplication of syncope in word-medial} position

\begin{tabular}{|c|c|c|c|}
\hline & Input & Output & Gloss \\
\hline a. & 7áktubu & *?aktbu & 'you (pl) write' \\
\hline b. & yíksiru & *yiksru & 'they break' \\
\hline c. & yikábbiru & *yikabbru & 'they bring up' \\
\hline d. & yigámmiru & *yigammru & 'to toast it' \\
\hline e. & Sállimu & *Tallmu & 'you teach him' \\
\hline F & kállimi & *kallmi & 'you (f) talk to' \\
\hline
\end{tabular}

As evident from the above examples, in normal speech syncope affects the second syllables in prosodic words but in fast speech the vowel in word-initial syllables is deleted. In what follows, I provide analyses of syncope in both normal and fast speech. The analysis is carried out in Stratal-OT. 


\section{Theoretical Framework}

\subsection{Optimality Theory}

The analysis of syncope as both normal and fast speech phenomenon of Makkan Arabic is done in the framework of Optimality Theory [15], and [16], and its offspring Correspondence Theory [17]. In this model, a grammar consists of two types of family constraints; markedness constraints and faithfulness constraints. Markedness constraints are universal and violable, but their ranking is parameterized and language specific. Faithfulness constraints, on the other hand, evaluate outputs and ensure faithful mapping between inputs and outputs. Evaluation of candidates over the entire constraints hierarchy is done in parallel fashion.

\subsection{Stratal-OT}

Stratal-OT [18] is a revival of Lexical Phonology theory [19], recast in a set of constraints. In Lexical Phonology theory [20], and [21] phonological rules are of two types; lexical and postlexical rules. At the lexical level, morphological information is important to the application of these cyclic rules. Furthermore, different rules apply at a given stratum. At the postlexical level, morphological information is no longer needed. As far as the postlexical level is concerned, two levels are assumed [3], each with different rules occurring at each level. These rules also apply word-internally as well as between words, provided that their structural description is met [3]. In Kaisse's [3] revised model of Lexical phonology, there are two postlexical level rules: rules of external sandhi (level 1), and rules of fast speech (level 2), which in turn feed into connected speech. In other words, connected speech rules are derived from fast speech rules [18], [19], and [3]. According to Kaisse and Shaw, [22:5] postlexical rules can create new structures and segment sequences but lexical rules are structure preserving. Furthermore, "postlexical rules can be optional and subject to variation due to rate of speech" [22:6].

\subsection{Motivating the Levels}

Two arguments prompt invoking two postlexical levels in Makkan Arabic (i.e., normal speech - level 1, and fast speech - level 2). First, syncope at each level occurs in different environments where at level 1 it occurs in word-medial position, but at level 2 it affects word-initial syllables. Second, syncope at postlexical level 1 targets $/ \mathrm{i} /$, but at level 2, both $/ \mathrm{i} /$ and $/ \mathrm{u} /$ are syncopated. Third, syncope in fast speech is an optional rule, however, in careful speech, it is obligatory and categorical. Furthermore, these arguments suggest that syncope in normal speech is phonological while it is phonetic in fast speech based on the fact that syncope as a phonetic process is not subject to the phonotactic constraints that are evident in normal speech.

\section{The Analysis}

Several analyses of Makkan syncope in normal speech have been carried out in an OT framework, for instance [9], [10], [11], and [12]. In this paper, only Kabrah [10] is incorporated because it is carried out in Stratal-OT. However, the paper will employ Gouskova's constraints [9] that account for syncope in MA. According to Gouskova [9], and based on Prince and Smolensky [15], the most harmonic peaks of syllables is the low vowel $a>u>i$. This is phonetically grounded in the fact that the low vowel is the most sonorant and therefore makes the best nucleus. As a result, when a low vowel occurs in open unstressed syllable it does not get deleted. The high vowels are not as sonorant and are therefore subject to deletion in open unstressed syllables.

Makkan syllable inventory includes CV, CVV, CVC, CVVC, and CVCC. The first three syllables can occur anywhere in the word but the superheavy syllables are restricted to word-final position [8]. In derived environments (at the postlexical level), only CVVC can occur medially, as a result of syncope. Words with underlying complex onsets are prohibited and are therefore repaired using epenthesis [8], and [10].

The stress generalizations are as follows: stress lodges on an ultimate syllable when it is superheavy (CVVC and CVCC) or CVV [8], [10]). In the absence of a superheavy syllable, the rightmost heavy syllable (CVV or CVC) is stressed. In odd number of light syllables, the antepenultimate syllable is stressed. However, in even number of light syllables the penultimate syllable is the stress bearer. Furthermore, Makkan observes a trisyllabic window restriction when stress is assigned [10]. Representative examples are given in (8).

\section{(8) Makkan stress generalizations}

\begin{tabular}{|c|c|c|c|}
\hline a. & $\begin{array}{l}\text { Ultimate stress CVV, } \\
\text { CVVC, and CVCC }\end{array}$ & $\begin{array}{l}\text { katabóo } \\
\text { kitáab } \\
\text { katábt }\end{array}$ & $\begin{array}{c}\text { 'they wrote } \\
\text { it(m)' } \\
\text { 'a book' } \\
\text { 'I/You } \\
\text { wrote' }\end{array}$ \\
\hline b. & $\begin{array}{c}\text { Penultimate stress CVC, and } \\
\text { CVV }\end{array}$ & $\begin{array}{l}\text { kasárha } \\
\text { țurráaha }\end{array}$ & $\begin{array}{c}\text { 'he broke it } \\
\text { (f)' } \\
\text { 'mattress' }\end{array}$ \\
\hline c. & Antepenultimate stress & $\begin{array}{l}\text { sáafaru } \\
\text { mírsama }\end{array}$ & $\begin{array}{l}\text { 'they } \\
\text { travelled' } \\
\text { 'pencil' }\end{array}$ \\
\hline d. & $\begin{array}{l}\text { Stress in odd and even } \\
\text { number of light syllables }\end{array}$ & $\begin{array}{c}\text { kátabu } \\
\text { gálamu } \\
\text { bagarátu } \\
\text { ragabátu }\end{array}$ & $\begin{array}{l}\text { 'they wrote' } \\
\text { 'his pen' } \\
\text { 'his cow' } \\
\text { his neck' }\end{array}$ \\
\hline
\end{tabular}

Kabrah [10] observes that syncope in Makkan Arabic is a postlexical process following stress assignment - which happens at the lexical level. Syllables that occupy the weak node of a foot are deleted. At postlexical 1, only the high 
front vowel gets deleted, however, at postlexical 2, both /i/ and $/ \mathrm{u} /$ are deleted.

\subsection{Syncope in Normal Speech}

I begin with analysis of syncope in normal speech then I proceed to fast speech. In normal speech the site of deletion is the second syllable in prosodic words. Note that a medial CVVC is derived as a result of deletion. The following constraints are needed.

\section{(9) *NUC i/u [9]}

High vowels cannot be peaks of syllables.

\section{(10) MAX-IO (V) [17]}

Deletion of vowels is prohibited.

Since it is more important to avoid a nucleus / $\mathrm{i} /$ than to delete a vowel, then the markedness constraint must dominate the faithfulness constraint.

\section{(11) *NUC/i » MAX-IO (V)}

Table 1. Constraint interaction at postlexical 1 Input /șaahibátu/ $\rightarrow$ [Șaahbátu]

\begin{tabular}{|l|c|c|}
\hline Input / Șahibátu/ & $*$ NUC/i & MAX-IO (V) \\
\hline a. Șahibátu & $* !$ & \\
\hline b. șa $\quad$ sahbátu & & $*$ \\
\hline
\end{tabular}

In Table 1 , deletion of the high vowel leaves $/ \mathrm{h} /$ as a stray consonant. Assigning the $/ \mathrm{h} / \mathrm{a}$ mora thus allowing it to act as coda to the first syllable yields an ill-formed syllable stemming from the fact that syllables in Makkan are maximally bimoraic. Syllabifying $/ h /$ as part of the second syllable forming a complex onset is also undesired because of a ban on syllables containing complex onsets. Shortening the vowel or inserting a vowel is also not allowed. The only way to syllabify $/ \mathrm{h} /$ is to adjoin it to the first syllable without assigning it a mora. This scenario is ultimately chosen if *TRIMORAIC SYLLABLE (which penalizes syllables with three moras) and COMPLEX ONSET are ranked higher than the metrical constraint WBYP (14). These scenarios are borne out in Table 2.

(12) Weight-By-Position (WBYP) [15] and based on [17]

Coda consonants are moraic.

\section{(13) * COMPLEX ONSET [15]}

Complex onsets are prohibited.

\section{(14) *TRIMORAIC, *COMPLEX ONSET »WBYP}

Table 2. Constraint Interaction at postlexical 1

Input /ṣaahibátu/ $\rightarrow$ [Ṣaahbátu]

\begin{tabular}{|c|c|c|c|}
\hline Input / Șaahibátu/ & $* 3-\sigma-\mu$ & $* \mathrm{C} / \mathrm{ONS}$ & WBYP \\
\hline Șaa.hba.tu & & $* !$ & \\
\hline b. $\mathrm{s}_{\mu} \mathrm{a}_{\mu} \hbar$.ba.tu & & & * \\
\hline c. $\quad S_{\varphi} a_{\mu} a_{\mu} \hbar_{\mu}$.ba.tu & $* !$ & & \\
\hline
\end{tabular}

Epenthesizing a vowel after $/ \mathrm{h} /$ allows it to act as onset to the newly created syllable, however, this is undesired if the constraint responsible for insertion is ranked higher than the metrical constraint as in (15). The interaction of the constraints is shown in Table 3 .

\section{(15) DEP-IO (V) » WBYP}

Table 3. Constraint Interaction at postlexical 1

Input /șaahibátu/ $\rightarrow$ [șaahbátu]

\begin{tabular}{|c|c|c|}
\hline & DEP-IO (V) & WBYP \\
\hline a. $\quad$ șa. ha.ba.tu & $* !$ & \\
\hline b. $\odot$ șa $\mathrm{a}_{\mu}$ h.ba.tu & & $*$ \\
\hline
\end{tabular}

The ranking in (11) also accounts for syncope in a sequence of light syllables. In Table 4, the winning candidates are (b) and (d).

Table 4. Syncope in a sequence of light

Syllables - Input /misik-u/ $\rightarrow[$ misku]

Input /širib-u/ $\rightarrow$ [širbu]

\begin{tabular}{|cc|c|c|}
\hline \multicolumn{2}{|c|}{ Input /misik-u/ } & $*$ NUCi/u & MAX-IO (V) \\
\hline a. & mi.si.ku & $* * * !$ & \\
\hline b. ${ }^{2} \quad$ mis.ku & $* *$ & $*$ \\
\hline \multicolumn{2}{|c|}{ Input / širib-u/ } & & \\
\hline c. & ši.ri.bu & $* * * !$ & $*$ \\
\hline d. & šir.bu & $* *$ & \\
\hline
\end{tabular}

However, in patterns of the broken plurals, syncope is blocked in CVCVCV words due to the highly ranked constraint TEMPLATE (proposed by Gafos [24]) which requires faithful mapping of templates. This is in line with research on the other Arabic dialects (e.g. in Egyptian Arabic syncope also underapplies in the broken plural such as tukusa 'taxis' [25].

Since TEMPLATE is satisfied at the cost of not deleting the high vowel, then TEMPLATE must dominate the markedness constraint as can be seen by the constraint ranking in (16).

\section{(16) TEMPLATE » *NUC i/u $\gg$ MAX-IO (V)}

Table 5. Failure of syncope in the broken plural Input /mudusu/ 'his slippers'

\begin{tabular}{|c|c|c|c|}
\hline & TEMPLATE & $*$ NUC i/u & MAX-IO \\
\hline a. mudusu & & $* * *$ & \\
\hline b. mudsu & $* !$ & $* *$ & $*$ \\
\hline & & & \\
\hline c. kutbu & $* !$ & $* *$ & $*$ \\
\hline d. kutubu & & $* * *$ & \\
\hline
\end{tabular}

In Table 5, candidate (a) bests it rival output (b) due to satisfaction of TEMPLATE rendering candidate (a) optimal despite incurring three violations of the markedness constraint.

Furthermore, high vowels are not deleted if they yield a syllable that contains either a complex onset or a complex coda in word-medial position, which are prohibited 
categorically at both lexical and postlexical levels, by the constraint in (17) and their ranking in (18).

\section{(17) *Word-Medial-COMPLEX}

Syllables that contain either complex onsets or codas are prohibited in word-medial position.

\section{(18) *Word-Medial-Complex » *NUC i/u »}

\section{MAX-I O (V)}

Table 6. Word-medial consonant cluster

Input /yíksir-u/ $\rightarrow$ [yiksiru]

Input /tikallim-i/ $\rightarrow$ [ tikallimi]

\begin{tabular}{|c|c|c|c|}
\hline CANDIDATES & *WMC & $\begin{array}{c}* N U C \\
i / u\end{array}$ & MAX- (V) \\
\hline a. yiksiru & & $* * *$ & \\
\hline b. yik.sru & $* !$ & $* *$ & $*$ \\
\hline c. $\quad$ yiks.ru & $* !$ & $* *$ & $*$ \\
\hline \multicolumn{4}{|l|}{ CANDIDATES } \\
\hline d. ${ }^{\infty}$ tikal.li.mi & & $* * *$ & \\
\hline e. tikal.lmi & $* !$ & $* *$ & * \\
\hline f. tikall.mi & $* !$ & $* *$ & $*$ \\
\hline
\end{tabular}

In Table 6, candidates (b) and (e), (c), and (f) are ruled out due to having either a complex onset or a complex coda in word-medial position, respectively. Candidate (a) wins despite having three marks of violations for $* \mathrm{NUC} \mathrm{i} / \mathrm{u}$. Output (d) bests its rival (e) by incurring three violations of *NUC i/u.

\subsection{Syncope in Fast Speech}

Syncope in fast speech is an optional process such that an input can have different outputs depending on the rate of speech; normal vs. fast. For instance, an input such as /bigaala/ 'supermarket' is realized as [bigaala] in careful speech but as [bgaala] in fast speech. Constraint ranking of normal speech is given first, followed by that of fast speech. Consider the constraint ranking in (19) followed by constraint interaction in Table 7.

\section{(19) *COMPLEX ONSET » *NUC i/u » MAX-IO (V)}

Table 7. Constraint interaction at postlexical 1

Normal speech Input / bigaala/ $\rightarrow$ [bigaala], Input /kilaab/ [kilaab]

\begin{tabular}{|c|c|c|c|}
\hline CANDIDATES & ${ }^{*}$ C/ONSET & $*$ NUC/i & MAX-IO (V) \\
\hline a. $*$ bigaala & & $*$ & \\
\hline b. bgaala & $* !$ & & $*$ \\
\hline CANDIDATES & $*$ C/ONSET & $*$ NUC/i & MAX-IO (V) \\
\hline c. $*$ kilaab & & $*$ & \\
\hline d. klaab & $* !$ & & $*$ \\
\hline
\end{tabular}

In normal speech (i.e., postlexical level 1) (Table 7), the constraint that prohibits complex onsets outranks *NUC/i, thus selecting candidates (a) and (c) as optimal.

However, in fast speech, *COMPLEX ONSET is demoted to a dominated status as the constraint ranking in
(20) demonstrates . Table 8 shows that the opposite ranking holds rendering candidates (b) and (d) as winners.

(20) *NUC i/u » *COMPLEX ONSET » MAX (V)

Table 8. Constraint interaction at postlexical 2 - fast speech: Input / bigaala/ $\rightarrow$ [bgaala],

Input/kilaab/ $\rightarrow$ [klaab]

\begin{tabular}{|c|c|c|c|}
\hline CANDIDATES & *NUC/i & ${ }^{*} \mathrm{C} / \mathrm{ONSET}$ & MAX-IO(V) \\
\hline a. bigaala & *! & & \\
\hline b. bgaala & & * & $*$ \\
\hline \multicolumn{4}{|l|}{ CANDIDATES } \\
\hline c. kilaab & $* !$ & & \\
\hline d. klaab & & * & * \\
\hline
\end{tabular}

It is noted that in fast speech, inputs containing high vowels in initial syllables are protected from deletion if the vowel occurring in the initial syllable is stressed in CVCVC-V patterns. The constraint that militates against underparsing of stressed syllables is given in (21).

\section{(21) MAX-STRESS-IO [26]}

Stressed vowels of inputs are mapped into their corresponding outputs.

The ranking of (21) with the other constraints in shown in (22)

\section{(22) MAX-STRESS » *NUC i/u » MAX-IO (V)}

Table 9. Constraint interaction in fast speech

Input /múdus-u/ $\rightarrow$ [múdusu]
\begin{tabular}{|cr|c|c|c|}
\hline \multicolumn{2}{|c|}{ CANDIDATES } & MAX-STRESS-IO & $\begin{array}{c}* \text { NUC } \\
\text { i/u }\end{array}$ & $\begin{array}{c}\text { MAX-IO } \\
(\mathrm{V})\end{array}$ \\
\hline a. & múdusu & & $* * *$ & \\
\hline b. mdusu & $* !$ & $* *$ & $*$ \\
\hline
\end{tabular}

In Table 9, output (a) is chosen over (b) due to a fatal violation of the faithfulness constraint MAX-STRESS.

In the remaining section of the analysis we consider two principles that play a role in the application of fast speech syncope depending on the type of cluster that deletion might result in. These include the sonority principle (SSP), and the Obligatory Contour Principle (OCP).

As we can see from the set of data given in (23), the consonant cluster at the onset contains consonants that do not adhere to the Sonority Sequencing Principle [27] thus suggesting that sonority does not have any bearing on fast speech syncope. Representative examples are given in (23), and the sonority constraint is expressed in (24).

\section{(23) COMPLEX ONSETS that violate the sonority} principle

\begin{tabular}{|c|c|c|c|}
\hline & Input & Output & Gloss \\
\hline a. & lisaan & lsaan & 'tongue' \\
\hline b. & ružuul & ržuul & 'legs/feet' \\
\hline c. & riћaab & rhaab & 'a proper name' \\
\hline d. & wilaada & wlaada & 'delivering a baby' \\
\hline e. & yiruuh & yruuћ & 'he goes' \\
\hline f. & mudarris & mdarris & 'teacher $(\mathrm{m})$ \\
\hline
\end{tabular}


(24) The Sonority Sequencing Principle (SSP -based on [27])

A complex onset rises in sonority.

Since it is evident from the above examples that forms that violate SSP do surface as such then this markedness constraint must rank lower than the markedness constraint banning syllables containing high vowels. This ranking is shown in (25) and its interaction with * $\mathrm{NUCi} / \mathrm{u}$ is given in Table 10 .

\section{(25) *NUC i/u » SSP, MAX-IO (V)}

Table 10. Constraint interaction: Input

\begin{tabular}{|c|c|c|c|}
\hline Input /lisaan/ & *NUCi/u & SSP & MAX-IO (V) \\
\hline a. lisaan & $* !$ & & \\
\hline b. lsaan & & $*$ & $*$ \\
\hline
\end{tabular}

The second principle in our discussion of fast speech syncope and the type of consonant cluster it creates is the Obligatory Contour Principle (OCP). The set of data in (5) shows that adjacent stridents are prohibited as well as stops that share the place of articulation. These facts are expressed by the conjoined constraints in (26) and (27), respectively. Local conjunction is a mechanism used in OT that allows the construction of a complex constraint that combines two simpler ones. The combined constraints are given in (26), and (27).

\section{(26) [ OCP [+COR] \& OCP [+STRIDENT] ]}

Adjacent coronal stridents are prohibited.

(27) [ OCP [+COR] \& OCP [-d.r] ]

Adjacent alveolar stops are prohibited.

The high ranking of (26) and (27) is evident in (28) and the place of the two in the overall constraint hierarchy is shown in Table 11.

\section{(28) $[$ OCP $[+$ cor $] \&$ OCP $[+$ str $]],[$ OCP $[+$ cor $] \&$ OCP} [ -d.r] ] »*NUC i/u » MAX-IO (V)

Table 11. Underapplication of syncope: Input

/ žuzuur/ $\rightarrow$ [žuzuur], Input / tidawwir/ $\rightarrow$ [tidawwir]

\begin{tabular}{|c|c|c|c|c|}
\hline CANDIDATES & $\begin{array}{c}\text { OCP } \\
(26)\end{array}$ & $\begin{array}{c}* \text { NUC } \\
\mathrm{i} / \mathrm{u}\end{array}$ & $\begin{array}{c}\text { OCP } \\
(27)\end{array}$ & $\begin{array}{c}\text { MAX- } \\
\text { IO(V) }\end{array}$ \\
\hline a. žuzuur & & $*$ & & \\
\hline b. žzuur & $* !$ & & & $*$ \\
\hline CANIDATES & & & & \\
\hline c. tidawwir & & $*$ & & \\
\hline d. tdawwir & & & $* !$ & $*$ \\
\hline
\end{tabular}

Both outputs (b), and (d) are ruled out by the conjoined constraints in (26) and (27), respectively, rendering (a) and (c) as optimal with minimal violations of the lowest ranked constraints.

\section{(29) Final Ranking:}

\section{Postlexical level 1 (careful speech)}

\section{a. *COMPLEX ONSET, TEMPLATE, WMC » *NUCI/U » MAX-IO (V) \\ b. $\quad 3-\mu-\sigma$, DEP-IO(V), *COMPLEX ONSET » WBYP \\ c. Postlexical level 2 (fast speech) \\ d. MAX-STRESS, OCP » *NUCI/U » *COMPLEX ONSET, SSP » MAX-IO (V)}

Differences between fast speech syncope and that of careful speech are captured by the the ranking in (29). What causes syllables in word-initial position to surface with complex onsets in fast speech is that the markedness constraint *COMPLEX ONSET is outranked by the other markedness constraint $* \mathrm{NUCi} / \mathrm{u}$, whereas in careful speech *COMPLEX ONSET is undominated resulting in categorical prohibition against syllables with complex onsets. Note that in fast speech, as shown in (29c) the only other constraints that outrank *Nuci/u, are MAX-STRESS and the OCP conjoined constraints, which are obeyed throughout the grammar.

\subsection{Discussion}

The analysis of syncope in both normal and fast speech has shown differences between the two. While complex onsets are banned categorically in normal speech they are tolerated in fast speech. This stems from the fact that they result from different types of processes, one phonological while the other phonetic. Furthermore, there is an asymmetry in the types of syllables that appear in speech depending on the rate one is using. CVCC syllables are only allowed in word-final position and this remains the same throughout the grammar, however, in fast speech, a complex onset is tolerated. So the question that poses itself here is: what causes such disparity between complex onsets and complex codas to the extent that the former are allowed in postlexical level 2 while the latter are banned throughout the grammar? A possible answer to this question lies in the fact that when consonants stand in coda position they are counted towards syllable weight and the syllable in MA is maximally bimoraic with final consonant extrametricality. Complex onsets, on the other hand, do not count in syllable weight and so they do not pose the same problem for a quantity sensitive language such as Makkan Arabic. Because of the difference in the nature of syncope in normal speech being phonological while in fast speech it is phonetic makes a complex coda subject to the sonority principle while complex onsets are not (i.e. at the phonetic level, the complex onset is not subject to phonotactic constraints). This is in line with findings in fast speech phenomena in other languages [22] where fast speech processes give rise to new structure that are otherwise not attested in the language.

\section{Evidence from other Arabic Dialects}

In normal speech, the Arabic dialects are divided into 
two groups; those that allow syllables with complex onsets such as Palestinian Arabic [29], Lebanese Arabic [30], and Syrian Arabic [31], just to name a few. The other group does not allow complex onsets in normal speech (e.g. Cairene Arabic [25], Makkan Arabic [8] and Sudanese Arabic [32].

\subsection{Syncope in Nhoolah Arabic Fast Speech}

The Nhoolah dialect is a variety of Hadramuti Arabic that bears some similarities to Makkan Arabic. In this dialect, syncope applies in word-medial position as well as in word-initial syllable [33]. Representative examples are given in (30), and (31).

(30) Medial syncope in Nhoola Arabic ([33]: 48 \& 50) (Normal speech)

\begin{tabular}{|c|c|c|c|}
\hline & Input & Output & Gloss \\
\hline a. & kubur-at & kubrit & 'she grew up' \\
\hline b. & kubur-an & Kubran & 'they grew up' \\
\hline c. & kubur-u & Kubru & 'they grew up' \\
\hline d. & șaahiba & șahba & 'a female friend' \\
\hline e. & daaxil-a & daaxla & 'coming in (f)' \\
\hline
\end{tabular}

(31) Syncope in Nhoolah Arabic - word-initial syllables ([33]: 52) (Fast speech

\begin{tabular}{|c|c|c|c|}
\hline & Input & Output & Gloss \\
\hline a. & nisiit & nsiit & 'I/you forgot' \\
\hline b. & kubur-t & kburit & 'I/you up' \\
\hline c. & simiS-ti & smiSti & 'you (f) heard' \\
\hline d. & kitaab & ktaab & 'a book' \\
\hline e. & duruus & druus & 'lessons' \\
\hline f. & guluub & gluub & 'hearts' \\
\hline
\end{tabular}

The syllable inventory of Nhoolah Arabic includes CV, CVC, CVV, CVVC, and CVCC. However, this dialect restricts the occurrence of some of these syllables. $\mathrm{CV}$ and CVV cannot occur in word-final position, due to a ban on open syllables in final position. Furthermore, CVCC occurs in word-final position only if the final complex is a geminate; otherwise the cluster has to be repaired by epenthesis (e.g.(31b)). CVVC can occur word-medially or in word-final position [33].

Bin Mahfous ([33]: 3) observes that when syncope applies to word-initial syllable, the complex onset does not always obey the sonority principle.

(32) Syncope in Nhooleh Arabic (Fast speech)

\begin{tabular}{|c|c|c|c|}
\hline & Input & Output & Gloss \\
\hline a. & bilaadana & blaadana & 'our village/country' \\
\hline b. & yinaam & ynaam & 'he sleeps' \\
\hline c. & misallahiin & msallahiin & 'they are armed' \\
\hline d. & ligaaluh & lgaaluh & 'he did to him/himself' \\
\hline
\end{tabular}

In analyzing syncope in this dialect, we can assume that the process of deletion in word-initial syllables is a phonetic process that is typically found in fast speech. On the other hand, syncope in word-medial position is a phonological process.

\subsection{Syncope in Cairene Arabic Fast Speech}

Based on a set of data I collected from two native speakers of Cairene Arabic (CA), I observed that speakers of this dialect allow complex onsets in fast speech. MA and $\mathrm{CA}$ are both onset dialects that share several similarities. CA permissible syllables are CV, CVV, CVV, CVVC and CVCC. The last two are restricted to word final position. In normal speech, CA does not allow complex onsets. However, in fast speech the high vowel in word initial syllable is deleted giving rise to syllables with complex onset as evident from the examples in (33).

\section{(33) Syncope in CA fast speech}

\begin{tabular}{|c|c|c|c|}
\hline & Input & Output & Gloss \\
\hline a. & țiwiil & țiiil & 'tall' \\
\hline b. & kibiir & Kbiir & 'big' \\
\hline c. & misaafir & msaafir & 'he's travelling' \\
\hline d. & mihaagir & mhaagir & 'he's immigrating' \\
\hline e. & miraat & mraat & 'wife' \\
\hline f. & ?uluub & ?luub & 'hearts' \\
\hline g. & ?ușayyar & ?șayyar & 'short (m)' \\
\hline h. & ?ulayyil & ?layyil & 'small (m)' \\
\hline i. & șuyayyar & Zyayyar & 'young (m)' \\
\hline j. & yustafandi & stafandi & 'tangerine' \\
\hline k. & bilaad & blaad & 'countries' \\
\hline l. & suguun & sguun & 'prisons' \\
\hline m. & wilaad & wlaad & 'boys' \\
\hline
\end{tabular}

\section{Conclusions}

The Makkan data lend evidence to the existence of two postlexical levels: postlexical level one (careful speech) and postlexical level 2 (fast speech). It also shows that one and the same process can apply at both levels. A process such as syncope in MA applies at both postlexical levels, however, it differs in the environments where each applies and the structures that each gives rise to (medial CVVC syllables vs. initial CCVVC syllables). Stratal-OT offers a unified analysis of both fast and careful speech syncope; it captures the differences between the two in terms of constraint ranking. Furthermore, when a process happens at the phonetic level, things are relaxed because these processes are not subject to phonotactic constraints such as the sonority principle. For instance, the created new syllables that include complex onsets are not subject to the SSP. There are, however, certain principles that have to be 
obeyed at all levels, such as the OCP and MAX-STRESS. The paper has also considered syncope as a fast speech phenomenon in dialects that are similar to Makkan Arabic, namely Cairene Arabic and Hadramoti Arabic and found that these dialects display the same behavior with respect to syncope in fast speech. Another finding of the paper is that syncope in normal speech deletes only the vowel /i/ but in fast speech both /i/ and /u/are syncopated.

\section{REFERENCES}

[1] Kulikov, Vladimir. 2012. Voicing and voice assimilation in Russian stops. University of Iowa dissertations. http://ir.uiowa.edu/etd/3327.

[2] Zwicky, Arnold M. 1972. “On Casual Speech,” papers from the eight regional meeting of the Chicago Linguistic Society, Paul M. Perantean, Judith N Levi, and Gloria C. Phares, eds.; Chicago, Illinois, 607-615.

[3] Kaisse, Ellen M. 1985. Connected Speech: The Interaction of Syntax and Phonology. New York: Academic Press, INC.

[4] Roca, Iggy, and Wyn Johnson. 1999. A course in Phonology. Blackwell Publishers: Malden, MA.

[5] Davidson, Lisa. 2006. Schwa elision in fast speech: segmental deletion or jestural overlap? Phonetic 63: 79-112.

[6] Ingham, Bruce. 1971. Some characteristics of Meccan speech. Bulletin of the School of Oriental Studies 34: 273-297.

[7] Bakalla, Mohammed. 1979. The morphological and phonological components of the Arabic verb (Meccan Arabic). Lebanon: Longman.

[8] Abu Mansour, Mahasen Hasan. 1987.Nonlinear Analysis of Arabic Syllabic Phonology With Special Reference to Makkan. University of Florida: Ph.D. Dissertation.

[9] Gouskova, Maria. 2003. Deriving Economy: Syncope in Optimality Theory. University of Massachusetts, Amherst: Ph.D. Dissertation. Rutgers Optimality Archive-6

[10] Kabrah, Rawiah S. 2004. Transparency and Opacity in the Phonology of Makkan Arabic-A Stratal-OT Theoretic Approach. Boston University, Boston: Ph.D. Dissertation.

[11] Abu Mansour, Mahasen Hasan. 1995. Optimality and conspiracy in the syllable structure of Arabic. In Papers in Optimality Theory, eds. Jill Beckman, Laura Walsh and Suzanne Urbanczyk, 1-20. Amherst, Massachusetts: GLSA Publications.

[12] Abu Mansour, Mahasen Hasan. 2011. Phrasal Syncope in Makkan Arabic: The Phonology-Syntax Interface.

[13] Cantineau, Jean. 1939. Remarquessur les paler de sedentaires syro-libano-palestinies. Bulletin de la Societe de Linguistique de Paris 40: 80-88.

[14] Al-Ageli, Hussain M. 1996. Syllabic and Metrical Structure in Tripolitanian Arabic: A comparative Study in the standard and Optimality Theory. University of Essex, United
Kingdom: Ph.D. Dissertation.

[15] Prince, Alan and Paul Smolensky. 2004. Optimality Theory: Constraint Interaction in Generative Grammar. Malden, MA, and Oxford, UK: Blackwell. [Revision of 1993 technical report, Rutgers University Center for Cognitive Science. Available on Rutgers Optimality Archive, ROA-537]

[16] McCarthy, John, and Alan Prince. 1993. Prosodic Morphology: Constraint Interaction and Satisfaction. Report. New Brunswick, NJ: Rutgers University Center for Cognitive Science. [Available on Rutgers Optimality Archive, ROA-482]

[17] McCarthy, John J., and Alan Prince. 1995. Faithfulness and Reduplicative Identity. In University of Massachusetts Occasional Papers in Linguistics 18, eds. Jill Beckman, and Laura Walsh Dickey and Suzanne Urbanczyk, 249-384. Amherst, Massachusetts: GLSA Publications.

[18] Kiparsky, Paul. 2001. Stems and Words: Stratal or Parallel OT. Handout. Talk given at the Massachusetts Institute of Technology Colloquia.

[19] Mohanan, K. P. 1982. Lexical Phonology. Ph.D dissertation, MIT. Distributed by Indiana University Linguistics Club.

[20] Kiparsky, Paul. 1982a. From cyclic phonology to lexical phonology. In Harry van der Hulst and Norval Smith (eds.) The structure of phonological representation. Vol. I.,131-175. Dordrecht: Foris.

[21] Kiparsky, Paul. 1982b. Lexical morphology and phonology in I.-S. Yong (ed.) Linguistics In the morning calm. Seoul: Hanshin, 3-91.

[22] Kaisse, Ellen M., and Patricia A. Shaw. 1985. On the theory of lexical phonology. In Phonology Yearbook 2 ed. by Colin J Ewen and John M. Anderson, 1-30. New York: Cambridge University Press.

[23] Hayes, Bruce. 1989. Metrical Stress Theory: Principles and Case Studies. Chicago: The University of Chicago Press.

[24] Gafos, Adamantios. 2003. Greenberg's Asymmetry in Arabic: A Consequence of Stem in Paradigms. Language, Volume 79, Number 2: 317-355.

[25] Broselow, Ellen. 1976. The phonology of Egyptian Arabic. University of Massachusetts, Amherst: Ph.D. Dissertation.

[26] Pater, Joe. 2000. Non-uniformity in English secondary stress: the role of ranked and lexically specified constraints. Phonology 2, 17: 237-274.

[27] Clements, G.N. 1990. The role of the sonority cycle in core syllabification. In Papers in Laboratory Phonology I: Between the Grammar and Physics of Speech, eds. John Kingston and Mary Beckman, 283-333. New York: Cambridge University Press.

[28] Moreton, Elliott, and Paul Smolensky. 2002. Typological consequences of local constraint conjunction. In the Proceedings of the $21^{\text {st }}$ West Coast conference in Formal Linguistics, eds. L. Mikkelsen and C. Potts. Somerville, MA: Cascadilla Press. Rutgers Optimality Archive-525.

[29] Abu-Salim, Issam. 1982. A reanalysis of some aspects of Arabic phonology: A metrical approach: University of Illinois at Urbana-Champaign: Ph.D. Dissertation. 
[30] Haddad, Gassan. 1983. Problems and issues in the phonology of Lebanese Arabic. University of Illinois at Urbana-Champaign: Ph.D. Dissertation.

[31] Adra, Mohamed Ali. 1999. Identity Effects and Opacity in Syrian Arabic: An Optimality Theory analysis. University of Illinois at Urbana-Champaign: Ph.D. Dissertation.

[32] Hamid, Abdel Halim. 1984. The phonology of Sudanese Arabic. University of Illinois at Urbana-Champaign: Ph.D. Dissertation.

[33] Bin Mahfous, Nada. 2012. An Autosegmental-Theoretic Approach Toward Describing Some Syllable Structure Rules in Hadhrami Arabic. Umm Al-Qura University, Makkah: MA research project. 